\title{
Effect of Chloride Ion on the Durability Properties of RC-65/35-BN Steel Fiber Reinforced Concrete
}

\section{Efecto del ion cloruro sobre las propiedades de durabilidad del concreto reforzado con fibras de acero RC-65/35-BN}

\author{
Aperador-Chaparro William \\ Universidad Militar Nueva Granada, Bogotá, Colombia \\ Departamento de Ingeniería Mecatrónica \\ E-mail: william.aperador@unimilitar.edu.co \\ Carrillo Julian \\ Universidad Militar Nueva Granada, Bogotá, Colombia \\ Departamento de Ingeniería Civil \\ E-mail:wjcarrillo@gmail.com \\ Cárdenas-Pulido Jhon \\ Universidad Militar Nueva Granada, Bogotá, Colombia \\ Departamento de Ingeniería Civil \\ E-mail: u1100907@unimilitar.edu.co
}

\begin{abstract}
The use of concrete reinforced with steel fibers is relatively limited in Latin America due to its high cost. However, its mechanical performance is very useful in the construction of reinforced concrete structures. This article describes and discusses the results of an experimental research, which reflects the chloride ion effects at a short term, on the durability properties of concrete reinforced with RC-65-35-BN steel fibers using dosages of 30 and $60 \mathrm{~kg} / \mathrm{m}^{3}$. In order to predict the effect of chloride ion on the steel fiber reinforced concrete, trends of corrosion were estimated during 56 days by half-cell potential and linear polarization resistance tests. Additionally, the surfaces of the steel fibers were analyzed by X-ray diffraction with the purpose to determinate the corrosion products that were generated. The obtained results demonstrates an adequate performance of the fibers embedded in the concrete for this phase of corrosion initiation, due to its low probability of corrosion.
\end{abstract}

Keywords: steel fibers, concrete, corrosion, half-cell potential, corrosion products.

\section{Resumen}

El uso del concreto reforzado con fibras de acero es relativamente limitado en Latinoamérica debido a su alto costo. Sin embargo, su desempeño mecánico es muy útil en la construcción de estructuras de concreto reforzado. Este artículo describe y discute los resultados de un estudio experimental que refleja el efecto del ion cloruro a corto plazo, sobre las propiedades de durabilidad del concreto reforzado con fibras de acero RC-65/35-BN usando dosificaciones de fibra de $30 \mathrm{~kg} / \mathrm{m}^{3}$ y $60 \mathrm{~kg} / \mathrm{m}^{3}$. Con el fin de predecir el efecto del ion cloruro sobre el concreto reforzado con fibras de acero, las tendencias de la corrosión se estimaron durante 56 días mediante ensayos de potencial de media celda y resistencia a la polarización lineal. Adicionalmente, las superficies de las fibras de acero se analizaron por difracción de rayos $\mathrm{X}$ con el propósito de determinar los productos de corrosión generados. Para esta fase de iniciación de la corrosión, los resultados obtenidos demuestran un adecuado desempeño de las fibras embebidas en el concreto debido a su baja probabilidad de corrosión.

Descriptores: fibras de acero, concreto, corrosión, potencial de media celda, productos de corrosión. 


\section{INTRODUCTION}

Due to the simplicity of construction and versatility of the steel fiber reinforced concrete (SFRC), its use has increased significantly in recent years. SFRC is currently used in many fields of the civil engineering such as airport pavements, industrial floors, hydraulic structures, beams and walls for buildings, supporting underground tunnels, coatings with shotcrete or sprayed concrete (Abbas et al., 2014; Mahmud et al., 2013; Caballero et al., 2013; Johnston, 1982; Ramzi y Omer, 1999).

The corrosion of the rebar by the action of the chloride ion is one of the main causes of the premature deterioration in concrete structures by oxidation of the rebar (Granju y Balounch, 2005). This deterioration is due to the urban and industrial development in coastal zones across the whole world, where the sea salt is one of the principal adverse factors. The chloride ions are found in a small quantity in the environment, and therefore, they may be present in products used in the concrete mix such a cement, coarse and fine aggregates and mixing water. The quantities of these products are low in comparison with the mass or the volume of other materials in the mix. By making use of such products, small amounts of chlorides ion are adding to the mix, especially when additives are used (Pereira de Oliveira et al., 2013). The threshold or concentration of chlorides necessary to break the passive layer of the steel is related to certain parameters such as contents of tricalcium aluminate $\left(\mathrm{C}_{3} \mathrm{~A}\right)$, tetracalcium of aluminoferrite $\left(\mathrm{C}_{4} \mathrm{AF}\right)$, $\mathrm{pH}$ and W/C ratio (Ramzi \& Omer, 1999). Due to the chloride ions, the medium resistivity decreased when the ionic concentration of the matrix pores increase, which increases the electric conductivity as well as the corrosion velocity.

The aim of this work is to assess the electrochemical behavior of the concrete reinforced with Dramix RC-6535-BN low carbon steel fibers at a short term (phase of corrosion initiation). The mixes of SFRC were exposed to penetration of aggressive agents (water, $3.5 \% \mathrm{NaCl}$ solution), and then the durability of the steel fibers because such exposure was evaluated.

\section{EXPERIMENTAL PROGRAM}

Type I Portland cement was used as cementitious material, including fly ash replacement of $10 \%$. The aggregates used for the concrete mix correspond to a fine gravel of grays tones having maximum size of $10 \mathrm{~mm}$, specific gravity of 2.64, and absorption of $3.07 \%$. Two kinds of sand were used; one from river and one from crag with specific surface area of $2470 \mathrm{~kg} / \mathrm{m}^{3}$ (3.02 and 1.49 fine- ness modules, respectively) and absorption of $0.77 \%$ and $0.79 \%$ respectively. A water/cement ratio of 0.58 and two different dosages of steel fibers were used for the concrete mixes. In addition, two plasticizer additives were used: Plastiment AD 20 (SIKA, 2013), and Sika Viscocrete 2100 (SIKA, 2012). The composition of the mix is summarized in Table 1.

The experimental tests were performed on specimens with steel fiber reinforced concrete (SFRC). Cylinders and beams having standard dimensions of $150 \times 300$ $\mathrm{mm}$ and $150 \times 150 \times 600 \mathrm{~mm}$, respectively, were cast. The specimens were cured by applying a curing membrane on their surfaces. The curing membrane was based on aqueous emulsion of paraffin, which guarantees the development of the concrete strength.

Hooked-end steel fibers having $0.55 \mathrm{~mm}$ of diameter and $35 \mathrm{~mm}$ of length, aspect ratio of 65 and low carbon content, were used (Bekaert, 2010). Fiber dosages $\left(D_{f}\right)$ of $30 \mathrm{~kg} / \mathrm{m}^{3}$ and $60 \mathrm{~kg} / \mathrm{m}^{3}$, corresponding to fiber volume fraction $\left(V_{f}\right)$ of $0.38 \%$ and $0.76 \%$, respectively, were used in this study. The steel of the fibers was corrugated and complied with the parameters of standard test method NTC 5214-10. The characteristics of the fibers are shown in Table 2. In the table, effective work area represents the area of all fibers embedded into each specimen considered for the electrochemical measurements.

Table 1. Mix proportions

\begin{tabular}{ccc}
\hline Material & Quantity, $\mathrm{kg} / \mathrm{m}^{3}$ & Density, $\mathrm{g} / \mathrm{cm}^{3}$ \\
\hline Cement & 321.3 & 3.12 \\
Fly Ash & 35.7 & 2.09 \\
Sand 1 & 695.6 & 2.62 \\
Sand 2 & 173.9 & 2.60 \\
Gravel & 869.5 & 2.43 \\
Water & 185.0 & - \\
\hline
\end{tabular}

Table 2. Description of the variables studied

\begin{tabular}{|c|c|c|c|}
\hline Variable & \multicolumn{3}{|l|}{ Description } \\
\hline \multirow{6}{*}{ Fiber } & Type & \multicolumn{2}{|c|}{ RC-65-35-BN } \\
\hline & Length & \multicolumn{2}{|c|}{35} \\
\hline & Diameter, $d_{f}, \mathrm{~mm}$ & \multicolumn{2}{|c|}{0.55} \\
\hline & Aspect ratio, $l_{f} / d_{f}$ & \multicolumn{2}{|c|}{$\sim 65$} \\
\hline & Tensile strength, $\mathrm{MPa}$ & \multicolumn{2}{|c|}{1345} \\
\hline & Young's modulus, $\mathrm{MPa}$ & \multicolumn{2}{|c|}{210000} \\
\hline \multirow{3}{*}{ Dosage } & $D_{f}, \mathrm{~kg} / \mathrm{m}^{3}$ & 30 & 60 \\
\hline & Volume fraction, $V_{f}, \%$ & 0.38 & 0.76 \\
\hline & Effective work area, $\mathrm{m}^{2} / \mathrm{m}^{3}$ mixture & 0.151 & 0.302 \\
\hline
\end{tabular}


Specimens with steel fibers were subjected to corrosion environments for monitoring the corrosion during 56 days, that is, they were immersed in potable water (A1) and in a solution having $3.5 \%$ of analytical sodium chloride Panreac PA131655.1211 NaCl 99.0\% (A2). Description and quantity of electrochemical tests are shown in Table 3. Tests were aimed at measuring the corrosion potential, current density and polarization resistance of SFRC specimens. After 28 days of curing of specimens, electrochemical measurements were recorded every 14 days, during 56 days: only at each measurement date, the SFRC specimens were removed from their environments and tested under immersion in a solution of distilled water. This study was aimed at starting the corrosion process through the chloride ion (phase of corrosion initiation), and analyzing the degradation of steel fiber reinforced concrete in terms of the time. For such purpose, SFRC was considered as a conductive material due to saturation of the pore network of the material, which leads conductivity between fibers. Furthermore, X Ray Diffraction (XRD) test was carried out on the steel fibers to determine corrosion products associated to the composition of fibers.

The electrochemical characterization was performed using a Gamry PCI-4 potentiostat/galvanostat, which uses the rest potential technique. Current density and linear polarization resistance (LPR) tests were performed using a cell composed by a counter-electrode of stainless steel, a reference electrode of $\mathrm{Cu} / \mathrm{CuSO} 4$ and the Dramix RC-65-35-BN steel fibers embedded in the concrete as a working electrode (assuming steel fibers embedded in the matrix were not interconnected). The linear polarization resistance tests were performed applying a low external potential $( \pm 20 \mathrm{mV})$ around the open circuit potential, where a resistance drop correction was first applied verifying that drop values were lower than $75 \Omega$. The measurements of the open circuit potential were taken in a time of 12000 seconds until stabilization of itself was reached. Figure 1 shows the setup of both current density and linear polarization resistance tests. For the corrosion potential tests, the setup was adapted from the study of Mangat and Gurusamy (1987) (Figure 2). Mangat and Gurusamy (1987) measured the half-cell potential of fibers exposed at the fractured face after flexure tests and applying $2000 \mathrm{cy}-$ cles of wetting and drying. During such test, the electrical reference and half-cell were fixed on the concrete surface (negative terminal), and the electrical connection to the steel fiber was then moved to the selected fibers (positive terminal) and finally half-cell potential of each fiber was recorded (Tran et al., 2015). As a working electrode, in this study, the SFRC specimens were first saw in the mid-high and then, the connection to fibers in the fractured face was made. Hence, mapping of measurements on selected fibers was conducted and the results were computed as the average from these embedded fibers in three SRFC specimens (for both cylinders and beams) that were considered at each measurement date. This average was considered due to the similarity between the measured values.

Table 3. Description and quantity of electrochemical tests

\begin{tabular}{|c|c|c|c|c|c|}
\hline \multirow{3}{*}{ Type of test } & \multirow{2}{*}{\multicolumn{2}{|c|}{$\begin{array}{c}\text { Environment } \\
\qquad \mathrm{A} 1 \\
D_{f}, \mathrm{~kg} / \mathrm{m}^{3}\end{array}$}} & \multirow{2}{*}{\multicolumn{2}{|c|}{$\begin{array}{c}\text { Environment } \\
\qquad \mathrm{A} 2 \\
D_{f}, \mathrm{~kg} / \mathrm{m}^{3} \\
\end{array}$}} & \multirow{3}{*}{$\begin{array}{c}\text { Total of } \\
\text { specimens }\end{array}$} \\
\hline & & & & & \\
\hline & 30 & 60 & 30 & 60 & \\
\hline $\begin{array}{c}\text { Corrosion potential } \\
I_{\text {corr }} \\
\end{array}$ & 9 & 9 & 9 & 9 & 36 \\
\hline $\begin{array}{c}\text { Polarization } \\
\text { resistance, } R_{p}- \\
\text { Current density, } i_{\text {corr }}\end{array}$ & 9 & 9 & 9 & 9 & 36 \\
\hline X Ray Diffraction & 9 & 9 & 9 & 9 & 36 \\
\hline
\end{tabular}

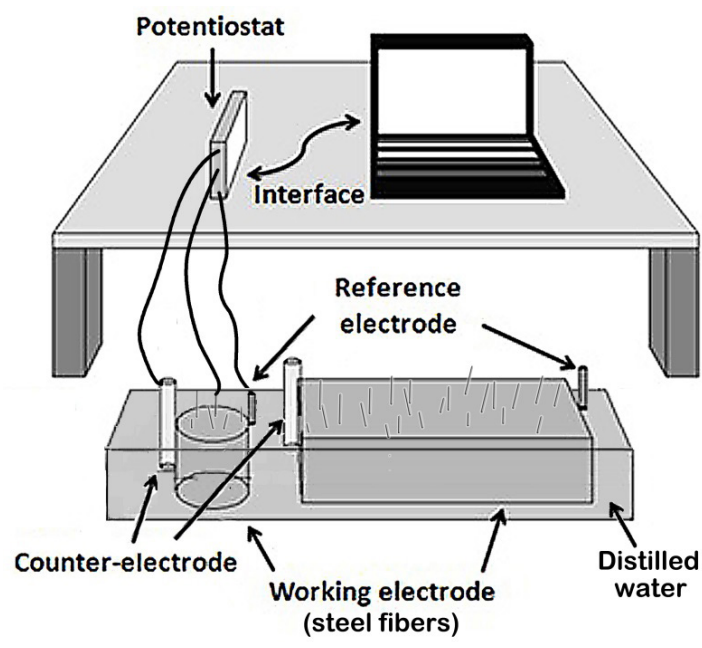

Figure 1. Setup of the electrochemical testing

It was also identified the corrosion products generated on the steel fibers surfaces by X-ray diffraction (XRD). The experimental setup of the X-ray diffraction test comprises a Goniometer having reference PW3050/60 $(\theta / \theta)$, which is managed under a XPERT-PRO system using a monochromatic radiation of $\mathrm{Cu} \mathrm{K} \alpha 1.54 \AA$ A. The Goniometer is operated at $40 \mathrm{kV}$ and $40 \mathrm{~mA}$ under temperature conditions of $25^{\circ} \mathrm{C}$. Scanning on the surface was performed from $2 \theta=20.01^{\circ}$ to $2 \theta=99.99^{\circ}$ with a step of $2 \theta=0.02^{\circ}$ at a scanning time of 1 second. The crystalline phases of the steel fibers surface was identified by an X-ray diffractometer having reference 
XPERT-PRO, and using the diffraction database of the equipment. In addition, it was used the MAUD software which is an analysis program based on Rietveld method. Such method consists in adjusting a theoretical diagram that coincide entirely with the observed diagram. The theoretical diagram is based on the crystalline structures and on series of crystalline parameters. The steel fibers were pull out of the concrete matrix and analyzed after 56 days of exposure to chloride ion (A2) and potable water (A1). For evaluating the reliability of the results obtained in the tests, statistical parameters such as arithmetic mean $(X)$ and the coefficient of variation $(\mathrm{CV})$ were utilized. Such parameters determines the average and the dispersion of the electrochemical measurements, respectively.

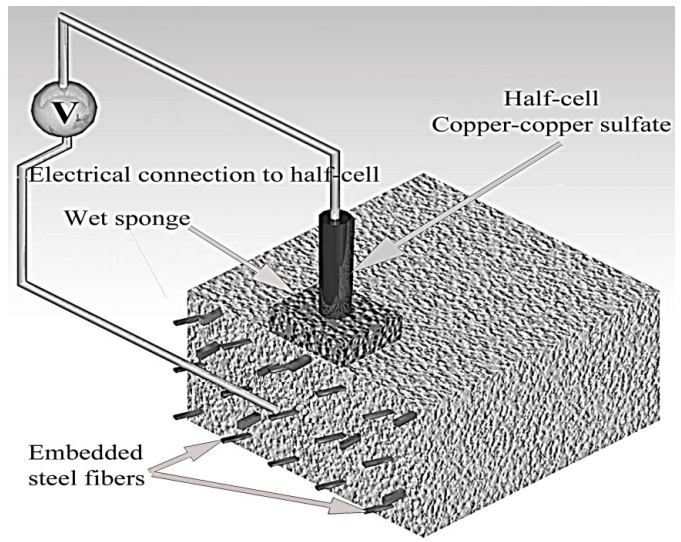

Figure 2. Setup of the electrochemical testing proposed by Mangat and Gurusamy (1987)

\section{Results AND DISCUSSION}

\section{CORROSION POTENTIAL}

The results of corrosion potential of SFRC specimens are shown in Table 4 and the mean values are plotted in Figure 3. Two trends regarding the low carbon steel fibers in the concrete are shown in Figure 3. One trend is related to the corrosion potential variation in function of the fiber dosage (30 and $\left.60 \mathrm{~kg} / \mathrm{m}^{3}\right)$, and other related to effect of chloride ion in the mixture at early ages. The obtained corrosion potentials of the concretes are shown in Figures $3 a$ and $3 b$ using graphics of corrosion potential versus evaluated time. This evaluation consisted in periodic measurements of corrosion potential (56 days). The criterion used for this evaluation was that specified by the ASTM C 876-09 standard test method. Corrosion monitoring was performed having the specimens immersed in water and simultaneously specimens exposed to chloride ion by immersion in a synthetic solution that simulated the seawater $(3.5 \% \mathrm{NaCl})$.
Using the concept specified by ASTM C 876-91, it can be observed that for the first level evaluated, corresponding to 28 days of curing ( 0 days in graph), and both fiber dosages of $30 \mathrm{~kg} / \mathrm{m}^{3}$ and $60 \mathrm{~kg} / \mathrm{m}^{3}$, has a potential that coincides with the zone of passivation. Measurements during the first 14 days showed that the specimens exposed to water (A1) and to chloride ion (A2) suffered a decrease of potential and passed to the appropriate area of possible corrosion. This is because at the end of this measurement, the potential are found in a region having $90 \%$ of probability of corrosion (also known as active corrosion region). For the third level of exposition (28 days), the specimens subjected to both environments showed an increment of the corrosion potential. Therefore, the values of corrosion potential moves towards a cathodic zone, which indicates that, the material search a better performance of the corrosion in these environments. Subsequently, for the fourth and fifth level of exposition (42 days and 56 days, respectively), the potential keeps steady for both fiber dosages and for the two evaluated environments (A1, A2), that is, the potential remains in a passive region. In addition, the effect of the chloride ion observed in the corrosion potential begins to oscillate in a range of \pm 10 $\mathrm{mV}$ from the third level of exposition. This behavior is not an indication of corrosion that could be generated by the depassivation.

\section{POLARIZATION RESISTANCE AND CURRENT DENSITY}

The results of polarization resistance of SFRC specimens are shown in Table 5 and the mean values are plotted in Figure 4a. Figure 4a shows the values of polarization resistance measured using the LPR technique. It is observed that the measured values are related to the concrete having fiber dosages of $30 \mathrm{~kg} / \mathrm{m}^{3}$ and $60 \mathrm{~kg} / \mathrm{m}^{3}$, and subjected to a solution having and not having chloride ion at all levels of evaluation. Overall, this polarization resistance value decreased gradually in each evaluated level. For both dosages, the SFRC specimens in presence of potable water (A1) exhibited a better behavior and experienced higher resistance values from the beginning of the evaluation, because this parameter was kept high until the last evaluated levels. Hence, it indicates that SFRC exhibited a higher value of resistance when it is not in contact with chloride ion. In contrasts, for both dosages, this parameter decrease in function of time for the concrete subject to chloride ion, that is, in the environment A2. Nonetheless as shown in Figure $4 \mathrm{a}$, the most efficient concrete mix was that having less quantity of fibers in the mix (Bartos, 1981). Such trend is associated to the lower exposure area of the steel fibers, which 
leads high values of polarization resistance in SFRC specimens.

The results of current density of SFRC specimens are shown in Table 6 and the mean values are plotted in Figure $4 \mathrm{~b}$. The current corrosion is an inverse function of polarization resistance in accordance with the established protection criterion for plain concrete. However, the specimens subjected to chloride ion showed low corrosion current values (Figure 3). Following the adopted cri- terion, SFRC specimens with exposition to chloride ion are in a level of low values of corrosion. SFRC specimens having $D_{f}=30 \mathrm{~kg} / \mathrm{m}^{3}$ and $D_{f}=60 \mathrm{~kg} / \mathrm{m}^{3}$, and subjected to a chloride ion showed a high corrosion density that increases from the beginning of exposure. For the time evaluated in this study, this increment keeps constant in the cathodic zone, which generates a low corrosion condition (Aperador et al., 2012).

Table 4. Results of corrosion potential tests for the SFRC specimens

\begin{tabular}{|c|c|c|c|c|c|c|c|}
\hline \multirow{2}{*}{\multicolumn{3}{|c|}{ Corrosion potential, $E_{c o r r}, \mathrm{~V}$}} & \multicolumn{5}{|c|}{ Time, days } \\
\hline & & & 0 & 14 & 28 & 42 & 56 \\
\hline \multirow{10}{*}{$D_{f}=30 \mathrm{~kg} / \mathrm{m}^{3}$} & \multirow{5}{*}{$\begin{array}{c}\text { not having chloride } \\
\text { ions (A1) }\end{array}$} & Specimen 1 & -0.156 & -0.984 & 0.106 & 0.130 & 0.127 \\
\hline & & Specimen 2 & -0.156 & -0.932 & 0.099 & 0.116 & 0.123 \\
\hline & & Specimen 3 & -0.166 & -0.926 & 0.112 & 0.127 & 0.128 \\
\hline & & $X$ & -0.159 & -0.947 & 0.106 & 0.124 & 0.126 \\
\hline & & $C V, \%$ & 2.96 & 2.75 & 5.01 & 4.85 & 1.49 \\
\hline & \multirow{5}{*}{$\begin{array}{l}\text { having chloride } \\
\text { ions (A2) }\end{array}$} & Specimen 1 & -0.149 & -0.957 & 0.031 & 0.010 & 0.123 \\
\hline & & Specimen 2 & -0.158 & -0.940 & 0.036 & 0.010 & 0.119 \\
\hline & & Specimen 3 & -0.156 & -0.928 & 0.033 & 0.011 & 0.120 \\
\hline & & $X$ & -0.154 & -0.942 & 0.033 & 0.010 & 0.121 \\
\hline & & $C V, \%$ & 2.51 & 1.26 & 6.23 & 4.71 & 1.40 \\
\hline \multirow{10}{*}{$D_{f}=60 \mathrm{~kg} / \mathrm{m}^{3}$} & \multirow{5}{*}{$\begin{array}{l}\text { not having chloride } \\
\text { ions (A1) }\end{array}$} & Specimen 1 & -0.092 & -0.930 & 0.096 & 0.084 & 0.136 \\
\hline & & Specimen 2 & -0.091 & -0.937 & 0.098 & 0.087 & 0.147 \\
\hline & & Specimen 3 & -0.100 & -0.943 & 0.102 & 0.073 & 0.133 \\
\hline & & $X$ & -0.094 & -0.937 & 0.099 & 0.081 & 0.139 \\
\hline & & $C V, \%$ & 4.28 & 0.57 & 2.52 & 7.43 & 4.33 \\
\hline & \multirow{5}{*}{$\begin{array}{l}\text { having chloride } \\
\text { ions (A2) }\end{array}$} & Specimen 1 & -0.095 & -0.088 & 0.165 & 0.135 & 0.120 \\
\hline & & Specimen 2 & -0.100 & -0.091 & 0.154 & 0.159 & 0.123 \\
\hline & & Specimen 3 & -0.092 & -0.101 & 0.157 & 0.152 & 0.130 \\
\hline & & $X$ & -0.096 & -0.093 & 0.159 & 0.149 & 0.124 \\
\hline & & $C V, \%$ & 3.44 & 5.98 & 2.92 & 6.76 & 3.38 \\
\hline
\end{tabular}


DOI: http://dx.doi.org/10.22201/fi.25940732e.2017.18n2.012

Effect of Chloride lon on the Durability Properties of RC-65/35-BN Steel Fiber Reinforced Concrete

Table 5. Results of polarization resistance tests for the SFRC specimens

\begin{tabular}{|c|c|c|c|c|c|c|c|}
\hline \multirow{2}{*}{\multicolumn{3}{|c|}{ Polarization resistance, $R p, \mathrm{k} \Omega \mathrm{cm}^{2}$}} & \multicolumn{5}{|c|}{ Time, days } \\
\hline & & & 0 & 14 & 28 & 42 & 56 \\
\hline \multirow{10}{*}{$D_{f}=30 \mathrm{~kg} / \mathrm{m}^{3}$} & \multirow{5}{*}{$\begin{array}{l}\text { not having chloride } \\
\text { ions (A1) }\end{array}$} & Specimen 1 & 103.1 & 96.2 & 100.2 & 97.7 & 98.2 \\
\hline & & Specimen 2 & 104.0 & 100.9 & 102.1 & 106.3 & 101.0 \\
\hline & & Specimen 3 & 99.6 & 100.3 & 108.0 & 110.9 & 106.4 \\
\hline & & $X$ & 102.2 & 99.1 & 103.4 & 105.0 & 101.9 \\
\hline & & $C V, \%$ & 1.86 & 2.11 & 3.21 & 5.21 & 3.34 \\
\hline & \multirow{5}{*}{$\begin{array}{l}\text { having chloride } \\
\text { ions (A2) }\end{array}$} & Specimen 1 & 106.3 & 82.3 & 96.8 & 94.9 & 88.5 \\
\hline & & Specimen 2 & 99.5 & 96.1 & 90.6 & 88.4 & 94.4 \\
\hline & & Specimen 3 & 100.3 & 86.4 & 88.2 & 96.8 & 90.0 \\
\hline & & $X$ & 102.0 & 88.3 & 91.9 & 94.0 & 91.0 \\
\hline & & $C V, \%$ & 2.98 & 6.55 & 3.94 & 3.83 & 2.75 \\
\hline \multirow{10}{*}{$D_{f}=60 \mathrm{~kg} / \mathrm{m}^{3}$} & \multirow{5}{*}{$\begin{array}{l}\text { not having chloride } \\
\text { ions (A1) }\end{array}$} & Specimen 1 & 100.3 & 92.0 & 85.9 & 94.5 & 95.4 \\
\hline & & Specimen 2 & 102.1 & 99.0 & 88.3 & 91.8 & 93.4 \\
\hline & & Specimen 3 & 92.0 & 97.1 & 98.9 & 96.4 & 96.2 \\
\hline & & $X$ & 98.1 & 96.0 & 91.0 & 94.2 & 95.0 \\
\hline & & $C V, \%$ & 4.48 & 3.08 & 6.21 & 2.00 & 1.24 \\
\hline & \multirow{5}{*}{$\begin{array}{l}\text { having chloride } \\
\text { ions (A2) }\end{array}$} & Specimen 1 & 104.1 & 95.3 & 83.9 & 80.3 & 85.1 \\
\hline & & Specimen 2 & 101.1 & 62.1 & 85.8 & 87.7 & 79.3 \\
\hline & & Specimen 3 & 88.9 & 87.9 & 90.9 & 86.6 & 81.4 \\
\hline & & $X$ & 98.0 & 91.8 & 86.9 & 85.0 & 82.0 \\
\hline & & $C V, \%$ & 6.71 & 3.30 & 3.40 & 3.84 & 2.92 \\
\hline
\end{tabular}

Table 6. Results of current density tests for the SFRC specimens

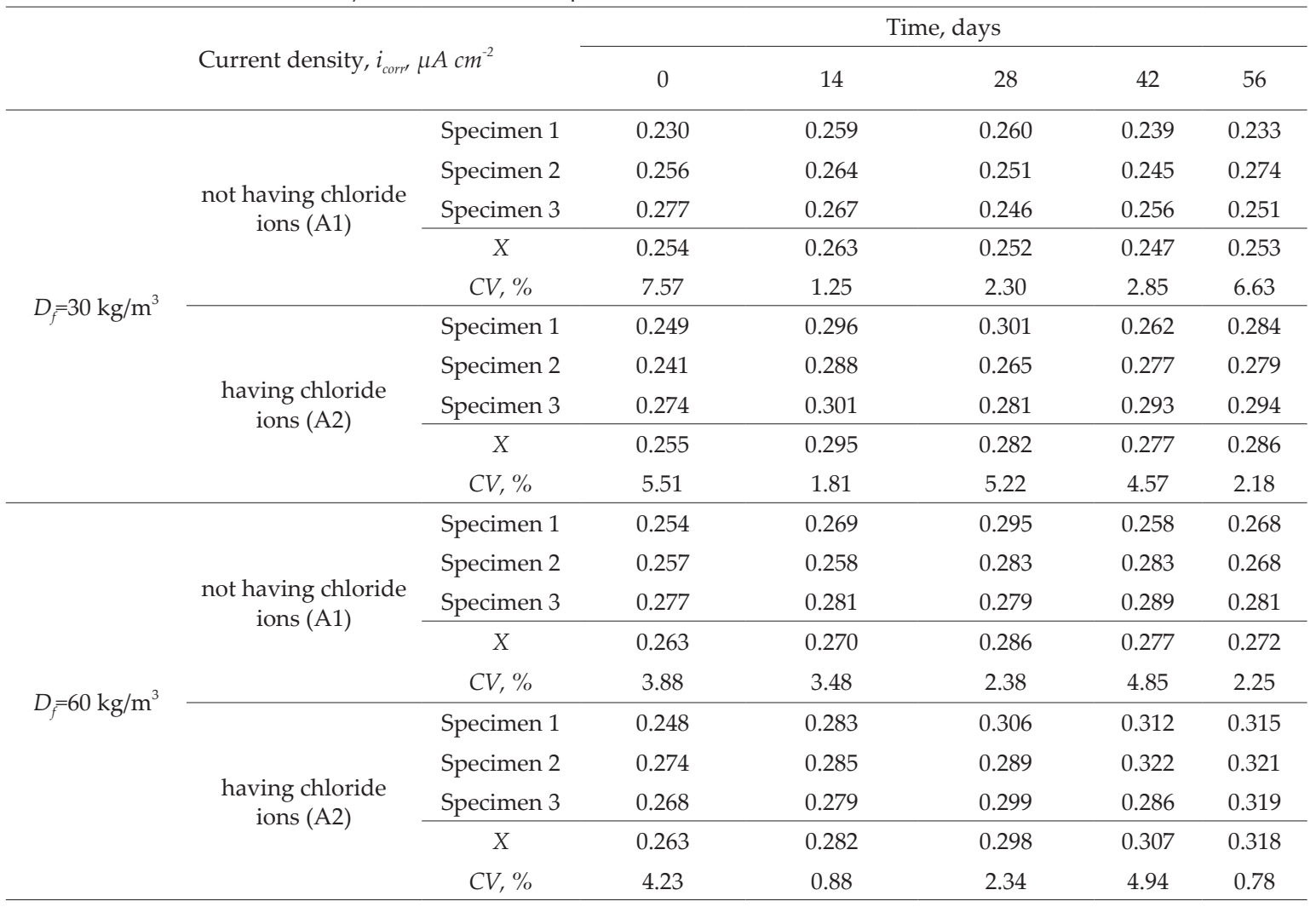




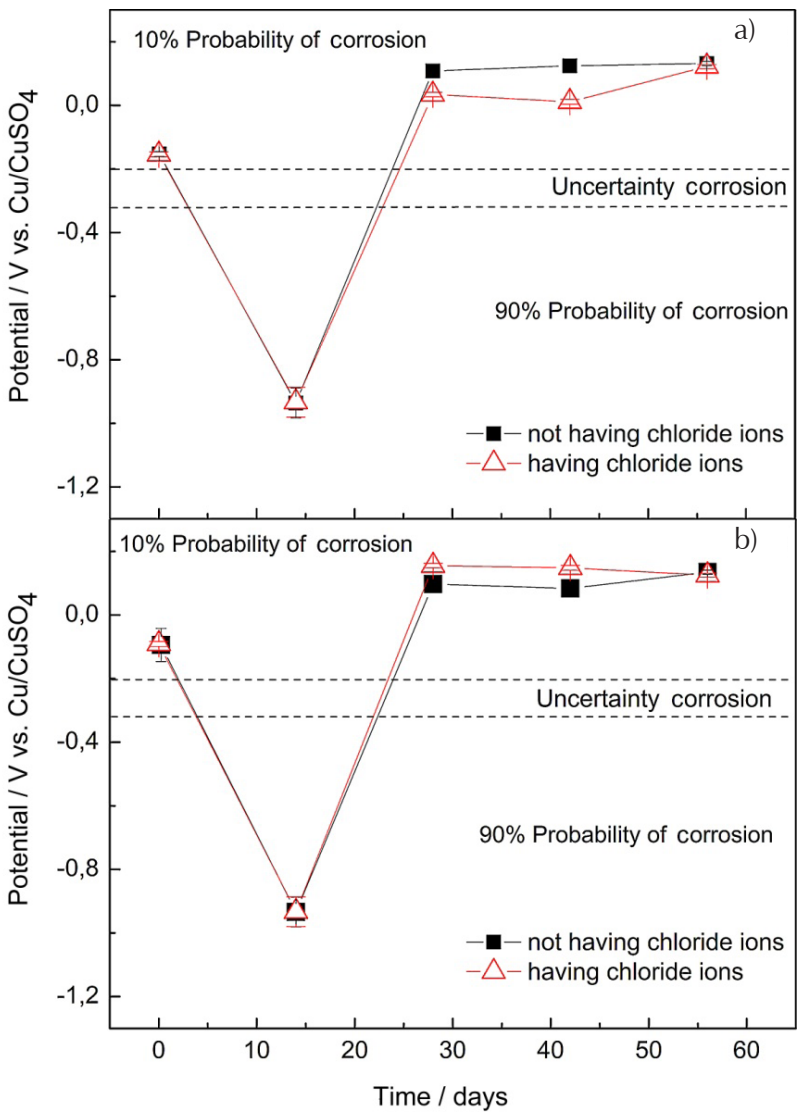

Figure 3. Corrosion potential for concretes with and without exposition to chloride ion, a) dosage of $30 \mathrm{~kg} / \mathrm{m}^{3}$, b) dosage of $60 \mathrm{~kg} / \mathrm{m}^{3}$

\section{XRD ANALYSIS}

The spectrum corresponding to steel fibers having and not having chloride ion is included in Figure 5. The figure shows the different phases that were obtained in the XRD spectrum. These phases are related to RC-6535-BN steel fibers exposed to the chloride ion, and are labeles as C: calcite, G: goethite, AN: andradite, H: halite, MG: magnetite, W: wüstite, L: lepidocrocite, HM: hematite and Q: quartz. Since one type of fiber was only used for SFRC, both specimens having $D_{f}=30 \mathrm{~kg} / \mathrm{m}^{3}$ and $D_{f}=60 \mathrm{~kg} / \mathrm{m}^{3}$, showed a similar behavior. The $\mathrm{Q}$ phase shows high intensity. Such intensity is related to the concrete matrix (cementitious materials and aggregates). The oxides found on the steel surface are MG and W. It is observed that, excluding the quartz, MG and $W$ phases show the greater intensity when comparing to the others phases and hydroxides belong to the G, L, and HM phases. Both the oxides and hydroxides registered in the spectrum are presented in the majority of the corrosion processes of low carbon steel fibers
(Choi et al., 2012). Overall, as shown in Figure 5, the spectrum shows the same phases for both fibers having and not having chloride ion. However, the spectrum of fibers having chloride ions has lower intensity.

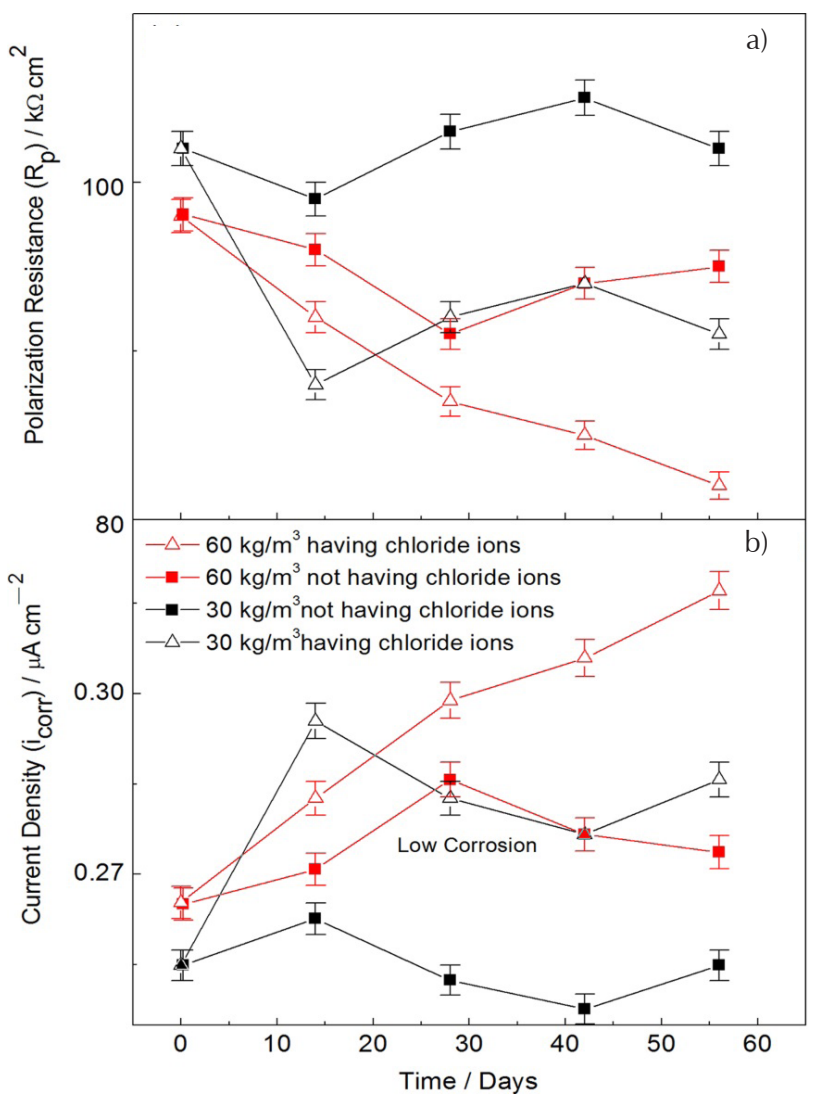

Figure 4. Polarization resistance and current density of the steel fibers embedded in Portland concretes with and without exposition to chloride ion

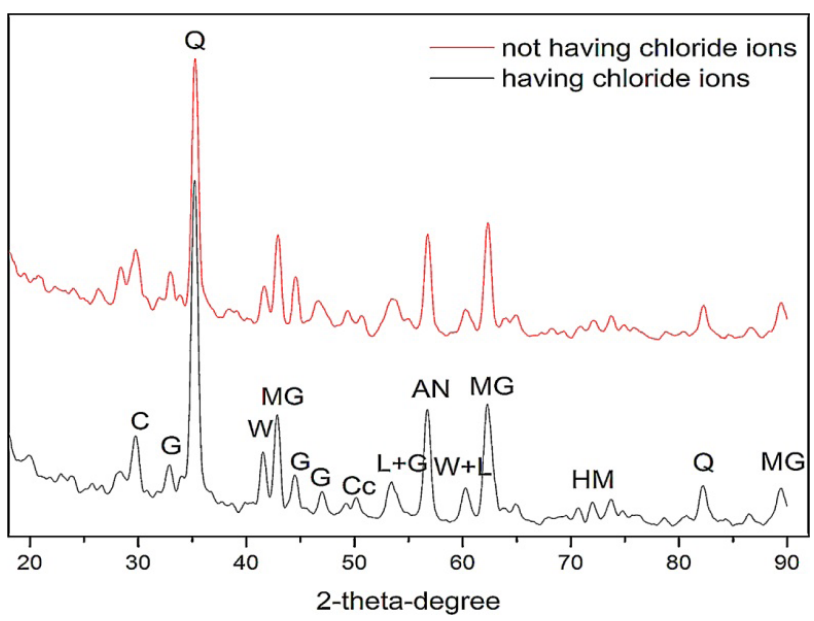

Figure 5. XRD spectrum of steel fibers with and without chloride ion 
When comparing the steel fibers having and not having exposition to chloride ion, it is observed that steel fibers not subjected to chloride ion have the highest peak corresponding to the quartz. Such trend is related to the adhesion of the metal surface with the concrete. In contrast, the steel fibers subject to chloride ion show the lowest peak due to the loss of adherence between matrix and the fibers. For both dosages, the generated corrosion products are linked basically to the degradation process of the steel.

\section{Conclusions}

The behavior of SFRC subjected to an environment having and not having exposure of chloride ion at a short term (phase of corrosion initiation) was assessed in this paper. The results measured in this study revealed the following conclusions:

- When concrete specimens reinforced with steel fibers using dosages of 30 and $60 \mathrm{~kg} / \mathrm{m}^{3}$ are subjected to an environment having and not having content of chloride ion, they experienced a passive behavior. This process is maintained until the end of the time evaluated (56 days). The analysis performed with the polarization resistance technique indicated that exposure of SRFC specimens to the chloride ion generates a decrease of the corrosion resistance as the dosage of fibers increase in the concrete mix. This trend is associated to greater exposure area when having higher fiber dosage. It is worth mentioning that despite the corrosion resistance values decrease, corrosion potential values for dosages of 30 and $60 \mathrm{~kg} / \mathrm{m}^{3}$ were similar because these concrete mixes were exposed at the same exposure medium. Therefore, the most efficient concrete mix was that having less quantity of fibers in the mix, because at higher fiber content, the SFRC specimens will be more prone to corrosion.

- The results obtained with the XRD technique showed that the proportion of goethite hydroxide is higher than the other products such as magnetite and wüstite. Such trend indicates that magnetite and goethite are products with higher intensity compared to the other phases found. However, it was also found lepidocrocite as other corrosion product. Comparing these results with the electrochemical measurements, it can be state that for the phase of corrosion initiation, the analyzed specimens generate the same content of corrosion products.

- For both dosages of fibers analyzed, SFRC specimens subjected to chloride ion showed high corrosion den- sity values. Nevertheless, these specimens remain in a passive region where a low probability of corrosion exists. Therefore, for the phase of corrosion initiation evaluated in this study, the SFRC subject to chloride ion showed a behavior, which does not affect the durability of the concrete specimens.

\section{ACKNOWLEDGEMENTS}

The authors wish to express their sincere thanks to Universidad Militar Nueva Granada to the funding received for the project ING-1572, as well as companies Argos and Proalco for donating the concrete mix and the fibers, respectively. Similarly, to engineers Sebastián Varela, Miguel Ospina and Felipe Riveros, and technical William Castaño for their support in the execution of tests.

\section{ReferenCES}

Abbas A.A., Syed-Mohsin S.M., Cotsovos D.M. Seismic response of steel fibre reinforced concrete beam-column joints. Engineering Structures, volume 59 (issue 2), May 2014: 261-283.

ASTM C 876-09 Standard, Standard test method for corrosion potentials of uncoated reinforcing steel in concrete, West Conshohocken, PA, American Society for Testing and Materials, 2009.

Aperador W., Bautista J.H., Torres R. Corrosion of reinforcing bars embedded in alkali-activated slag concrete subjected to chloride attack. Materials Research, volume 15, (issue 1), February 2012: 57-62.

Bartos P. Review paper: Bond in fibre reinforced cements and concretes. International Journal of Cement Composites and Lightweight Concrete, volume 3 (issue 3), August 1981: 159-177.

Bekaert (2010). Product Data Sheet Dramix RC-65/35-BN, Zwevegem, Belgium.

Caballero-Morrison K.E., Bonet J.L., Navarro-Gregori J., Serna P. An experimental study of steel fiber-reinforced high-strength concrete slender columns under cyclic loading. Engineering Structures, volume 57 (issue 12), December 2013: 565-577.

Choi S.J., Hong B.T., Lee S.J., Won J.P. Shrinkage and corrosion resistance of amorphous metallic-fiber-reinforced cement composites. Composite Structures, volume 107 (issue 1), January 2014: 537-543.

Granju J.L., Balouch S.U. Corrosion of steel fibre reinforced concrete from the cracks. Cement and Concrete Research, volume 35 (issue 3), March 2005: 572-577.

Johnston C.D. Steel fibre-reinforced concrete - present and future in engineering construction. Composites, volume 13 (issue 2), April 1982: 113-121.

Mangat P.S. y Gurusamy K. Corrosion resistance of steel fibres in concrete under marine exposure. Cement and Concrete Research, volume 18 (issue 1), July 1987: pp. 44-54. 
Mahmud G.H., Yang Z.J., Hassan A.M.T. Experimental and numerical studies of size effects of Ultra High Performance Steel Fibre Reinforced Concrete (UHPFRC) beams. Construction and Building Materials, volume 48 (issue 11), November 2013: 1027-1034.

NTC-5214 (2010). Fibras de acero para refuerzo de concreto. NTC 5214. Instituto Colombiano de Normas Técnicas y Certificación, Bogotá D.C., p.9.

Pereira de Oliveira L.A., Castro-Gomes J.P., Bernardo L.F.A., Ramos M.M.M. Evaluation of dry mortar ratio as mix design parameter for steel fibre reinforced self compacting concrete. Construction and Building Materials, volume 40 (issue 3), March 2013: 642-649.

Ramzi B.A.A. y Omer Q.A. Flexural strength of reinforced concrete T-beams with steel fibers. Cement and Concrete Composites, volume 21 (issue 4), August 1999: 263-268.

SIKA (2012). Product Data Sheet Viscocrete 2100, New Jersey, USA.

SIKA (2013). Product Data Sheet Plastiment AD 20, New Jersey, USA.

Tran N.T., Pyo S., Kim D.J. Corrosion resistance of strain-hardening steel-fiber-reinforced cementitious composites. Cement and Concrete Composites, volume 63, October 2015: 17-29.

\section{Suggested citation:}

\section{Chicago style citation}

Aperador-Chaparro, William, Julián Carrillo, Jhon Cárdenas-Pulido. Effect of Chloride Ion on the Durability Properties of RC-65/35-BN Steel Fiber Reinforced Concrete. Ingeniería Investigación y Tecnología, XVIII, 02 (2017): 139-147.

\section{ISO 690 citation style}

Aperador-Chaparro W., Carrillo J., Cárdenas-Pulido J. Effect of Chloride Ion on the Durability Properties of RC-65/35-BN Steel Fiber Reinforced Concrete. Ingeniería Investigación y Tecnología, volume XVIII (issue 2), April-June 2017: 139-147.

\section{About the authors}

William Aperador-Chaparro. He received the decree of physical in 2003 and master in metallurgy and materials science in 2006 by Universidad Pedagógica y Tecnológica de Colombia and PhD in materials engineering in 2009 by Universidad del Valle, Colombia. He made an international internship at Centro Nacional de Investigaciones Metalúrgicas (CENIM) in Madrid, Spain, in Laboratory of Engineering Materials and Durability. He is currently professor and chief scientist of Research Group GMCDP-VOLTA. He has been author and co-author of over 80 articles and has presented 40 international papers and 38 national communications.

Julián Carrillo. He received the degree of civil engineering in 2002 from the Universidad Militar Nueva Granada, UMNG, Colombia, master in civil engineering (area of structures and earthquakes) in 2004 from the Universidad de los Andes, Colombia, and Doctor of Engineering (area of Structures) in 2010 from the Universidad Nacional Autónoma de México, UNAM. He is currently associate professor in the Department of Civil Engineering at UMNG. He is member of three committees in the American Concrete Institute, ACI: 314, Simplified design of buildings; 369 Seismic repair and rehabilitation; and 374 Performance-based seismic design of concrete buildings.

Jhon Cárdenas-Pulido. He received the degree of Civil Engineering in 2013 from the Universidad Militar Nueva Granada, UMNG, Colombia. He is currently studying a master in civil engineering (area of structures and earthquakes) at the Universidad de los Andes, Colombia; and he is research assistant at the Research Group GMCDP-VOLTA of UMNG. 